\title{
EKSPERIMENTASI MODEL PEMBELAJARAN PROBLEM BASED LEARNING DAN MODEL DISCOVERY LEARNING SERTA MODEL THINK PAIR SHARE MATERI KUBUS DAN BALOK DITINJAU DARI KATEGORI KECERDASAN EMOSIONAL PADA KEMAMPUAN BERPIKIR MATEMATIS TINGKAT TINGGI PESERTA DIDIK SMP NEGERI KELAS VIII DI KABUPATEN SUKOHARJO
}

\author{
Yudi Pramono Pawiro ${ }^{1}$ Budiyono $^{2}$, Isnandar Slamet ${ }^{3}$ \\ ${ }^{1,2,3}$ Prodi Magister Pendidikan Matematika, FKIP Universitas Sebelas Maret Surakarta
}

\begin{abstract}
The objective of this research was to know the effect of the learning models on the high order mathematical thinking skill viewed from the emotional quotient of the students. The learning models compared were model of the PBL, model of the DL and model of the TPS. This research used the quasi experimental research. It's population was all of the students in Grade VIII of State Junior Secondary Schools in Sukoharjo. The samples of the research were taken by using the stratified cluster random sampling technique and consisted of 253 students. They were grouped into three classes, namely: 87 in Experimental Class 1, 84 in Experimental Class 2, and 83 in Experimental Class 3. The instruments to gather the data were test of high order mathematical thinking skill on the learning topic of cube and beam, and emotional quotient questionnaire. The proposed hypotheses of the research were analyzed by using the two way analysis of variance with unbalanced cells. The results of the research were as follows. 1) Model of the PBL results in a better high order mathematical thinking skill than model of the DL, and model of the TPS. Model of the DL results same high order mathematical thinking skill with TPS. 2) Emotional quotient gives students a different effect on high order mathematical thinking skill on the learning topic of cube and beam. The students with the high emotional quotient have a better high order mathematical thinking skill than those with the moderate emotional quotient and those with the low emotional quotient, the students with the moderate emotional quotient have a better high order mathematical thinking skill than those with the low emotional quotient. 3) There was no interaction the aforementioned learning models and the categories of the emotional quotient on the high order mathematical thinking skill of the students.
\end{abstract}

Keywords: PBL, DL, TPS, High Order Mathematical Thinking Skill and Emotional Quotient.

\section{PENDAHULUAN}

Kedudukan matematika sebagai ilmu dasar memegang peranan yang sangat penting dalam proses pembelajaran. Mengingat perannya sangat penting, perlu adanya perhatian khusus terhadap pembelajaran matematika. Dalam hal kemampuan berpikir kritis yaitu kemampuan berpikir tingkat tinggi, perlu mendapat perhatian serius. Tentang penelitian TIMSS tahun 1999, Suryadi (2005) mengemukakan, "Hasil studi internasional dalam bidang matematika dan IPA (TIMSS) untuk kelas delapan SLTP, mengindikasikan bahwa soal-soal matematika tidak rutin yang memerlukan berpikir tingkat tinggi pada umumnya tidak berhasil dijawab dengan benar oleh peserta didik Indonesia yang ikut dalam TIMSS". 
Di Indonesia sejak tahun 2002 telah berlangsung Olimpiade Sains Nasional (OSN). Sejak itu, OSN diselenggarakan setiap tahun hingga tahun 2014 ini. Olimpiade sains akan membiasakan peserta didik untuk berpikir logis, kritis, dan terstruktur dalam menemukan jawaban terhadap berbagai persoalan (Depdiknas, 2014). Soal pada OSN lebih banyak bersifat terbuka (open-ended) menekankan pemecahan masalah dan menuntut kemampuan berpikir tingkat tinggi (Suardana, 2012).

Jawa Tengah menjadi juara umum terbanyak dari 12 OSN yang diselenggarakan mampu meraih 8 kali juara umum. Namun berdasarkan data yang diperoleh untuk bidang matematika sekolah yang mewakili kejuaraan hanya berasal dari kota atau kabupaten tertentu yang setiap tahunnya diikutsertakan dalam OSN. Jawa Tengah sebagai provinsi yang terdiri dari 6 kota dan 29 kabupaten yang terdiri atas beberapa sekolah hanya didominasi oleh sekolah-sekolah yang berada di kota atau kabupaten tertentu. Hal ini diperkuat dengan hasil olimpiade tingkat provinsi atau Olimpiade Sains Provinsi (OSP) yang diadakan oleh Provinsi Jawa Tengah. Pada hasil OSP 2014, peserta didik dari Kabupaten Sukoharjo memperoleh peringkat ke 25 dari 35 peserta didik. Hal ini menunjukkan rendahnya prestasi peserta didik di Kabupaten Sukoharjo dalam matematika, khususnya dalam menjawab soai-soal yang menuntut berpikir matematis tingkat tinggi jika dibandingkan dengan kota dan kabupaten lainnya di Jawa Tengah. Hasil yang masih rendah ini dapat dilihat dari rata-rata prestasi peserta didik di Kabupaten Sukoharjo yang dibawah dari rata-rata provinsi.

Hasil penelitian World Bank, tahun 2007 dan 2011 dari segi proses pembelajaran, kegiatan guru berceramah menunjukkan peningkatan, sementara interaksi guru-peserta didik, kegiatan peserta didik melakukan diskusi, ekplorasi, dan investigasi terkait gagasan-gagasan matematika menunjukkan penurunan. Hal ini diperkuat dengan laporan hasil studi Henningsen dan Stein, 1997; Peterson, 1998; Mullis, dkk, 2000 (Suryadi, 2005) yang mengungkapkan bahwa pembelajaran matematika pada umumnya belum memfokuskan pada pengembangan kemampuan berpikir tingkat tinggi. Padahal kegiatan pembelajaran dimana peserta didik bereksplorasi dan melakukan investigasi atau penemuan akan melatih peserta didik dalam menemukan strategi dan berpikir tingkat tinggi dalam memecahkan masalah (Tim USAID, 2014). Sementara itu, penelitian yang dilakukan di Amerika Serikat oleh Thomson (2008) menunjukkan bahwa guru matematika memiliki kesulitan menafsirkan keterampilan berpikir dalam taksonomi Bloom dan membuat tes item untuk berpikir tingkat tinggi. Akibatnya, peserta didik umumnya belajar matematika tanpa mampu menggunakan pengetahuan mereka untuk memecahkan masalah dalam situasi beragam atau non rutin. 
Peserta didik antara lain masih sering mengalami kesulitan bila berhadapan dengan soal atau masalah yang menuntut berpikir tingkat tinggi (analisis, evaluasi, dan kreasi) atau masalah yang harus diselesaikan dengan cara-cara tidak rutin (Tim USAID, 2014). Lebih lanjut, dalam hasil survey Programme for International Student Assessment (PISA) 2000/2001 menunjukkan bahwa peserta didik lemah dalam geometri, khususnya dalam pemahaman ruang dan bentuk. Sebagai ilustrasi, peserta didik menghadapi kesukaran dalam membayangkan suatu balok yang berongga di dalamnya (Suwaji, 2008).

Salah satu alternatif tersebut diadakannya penelitian mengenai eksperimentasi model pembelajaran yang memberikan peluang bagi peserta didik untuk mengembangkan kemampuan berpikir tingkat tinggi. Beberapa model pembelajaran yang dipandang sejalan dengan hal itu, yaitu: model problem based learning (PBL) dan discovery learning (DL) serta cooperative learning tipe think pair share (TPS). Pada pembelajaran PBL situasi atau masalah autentik menjadi titik tolak pembelajaran untuk memahami konsep, prinsip dan mengembangkan keterampilan matematik (Suparlan, 2005). Menurut Duch (Asep, 2010) masalah yang baik yang disiapkan oleh guru akan memotivasi peserta didik untuk menyelidiki pengertian yang lebih dalam tentang suatu konsep.

Menurut Wilcox (Hosnan, 2014), pada DL peserta didik didorong untuk belajar sebagaian besar melalui keterlibatan mereka sendiri dengan konsep-konsep dan prinsipprinsip, dan guru mendorong peserta didik untuk memiliki pengalaman dan melakukan percobaan yang memungkinkan mereka menemukan prinsip-prinsip untuk diri mereka sendiri. Model pembelajaran TPS adalah model pembelajaran TPS juga merupakan model pembelajaran kooperatif yang mengelompokkan peserta didik menjadi beberapa kelompok kecil, yang memberikan kesempatan pada peserta didik untuk bisa saling berdiskusi mengenai materi yang sedang dibahas, namun peserta didik hanya berpasangan (berdua) dan waktu yang diberikan untuk berpasangan hanya sekitar 5-10 menit, artinya waktu yang digunakan untuk diskusi relatif sedikit.

Berdasarkan uraian, terdapat perbedaan antara ketiga model pembelajaran tersebut. Hal ini menarik perhatian bagi peneliti untuk melakukan eksperimentasi terhadap ketiga model pembelajaran tersebut pada kemampuan berpikir matematis tingkat tinggi. Selanjutnya, peneliti merasa perlu mengkaitkan antara ketiga model tersebut pada kemampuan berpikir matematis tingkat tinggi dengan kecerdasan emosional, sebab emosi yang terkelola dengan baik, peserta didik tidak akan mengalami banyak kesulitan dalam berinteraksi dengan masalahnya. Menurut Wilding (Soebyakto, 2012) kecerdasan emosional merupakan kecerdasan yang sangat penting bagi manusia sebagai salah satu solusi bagi mereka untuk menjadi sukses dengan orang lain. Hal ini karena kecerdasan emosional merupakan soft skill yang berkualitas tinggi. 
Kecerdasan Emosional juga melibatkan kemampuan untuk melaksanakan penalaran akurat tentang emosi dan menggunakan emosi dan emosional pengetahuan untuk meningkatkan berpikir (Goroshit dan Hen, 2012). Hal ini senada dengan penelitian yang dilakukan oleh Chabeli (2006) menyatakan ada hubungan antara pemikiran kritis dan kecerdasan emosional dalam berpikir kritis menyediakan alat-alat mental diperlukan secara eksplisit memahami bagaimana penalaran bekerja dan bagaimana alat tersebut dapat digunakan untuk mengambil perintah dari apa yang kita berpikir, merasa, keinginan dan melakukan. Memperhatikan uraian di atas, peneliti terdorong untuk melakukan penelitian yang memfokuskan pada eksperimentasi model PBL, model DL, dan model TPS ditinjau dari kecerdasan emosional peserta didik terhadap kemampuan berpikir matematis tingkat tinggi Sekolah Menengah Pertama di Kabupaten Sukoharjo.

\section{METODE PENELITIAN}

Penelitian ini adalah penelitian eksperimental semu dengan desain faktorial $3 \times 3$. Populasi penelitian ini adalah seluruh peserta didik SMP Negeri seKabupaten Sukoharjo. Sampel diambil secara acak dari SMP Negeri se-Kabupaten Sukoharjo dengan teknik Stratified Cluster Random Sampling. Sampel yang diperoleh adalah peserta didik SMP Negeri 1 Polokarto, peserta didik SMP Negeri 2 Mojolaban dan peserta didik SMP Negeri 2 Polokarto.

Variabel terikat penelitian ini yaitu kemampuan berpikir matematis tingkat tinggi (KBMT) dan variabel bebasnya yaitu model pembelajaran dan kecerdasan emosional. Untuk mengumpulkan data digunakan metode dokumentasi, angket dan tes. Metode dokumentasi digunakan untuk mengumpulkan data kemampuan awal peserta didik yang diambil dari nilai rapor matematika semester 1 kelas VIII. Metode angket tes digunakan untuk mengetahui tingkat kecerdasan emosional peserta didik dan metode tes digunakan untuk mengumpulkan data KBMTT. Sebelum dilakukan eksperimen, dilakukan uji keseimbangan dengan uji prasyarat awal meliputi uji normalitas populasi menggunakan metode Lilliefors dan uji homogenitas variansi populasi menggunakan metode Bartlett. Uji keseimbangan menggunakan analisis variansi satu jalan. Diperoleh hasil, ketiga sampel berasal dari populasi yang berdistribusi normal, homogen, dan memiliki kemampuan awal yang sama.

Sebelum instrumen tes KBMTT digunakan terlebih dahulu diadakan validitas isi, uji tingkat kesukaran, uji daya pembeda, dan uji reliabilitas. Soal dikatakan baik jika memenuhi kriteria yaitu valid, tingkat kesukaran $(0,3 \leq P \leq 0,7)$, daya beda $\left(r_{x y} \geq 0,3\right)$ dan reliabilitas $\left(r_{11} \geq 0,7\right)$. Dari 8 butir soal yang diujicobakan terdapat 4 butir soal yang digunakan. Untuk angket kecerdasan emosional sebelum digunakan, terlebih dahulu 
diadakan validasi isi, uji konsistensi internal, dan uji reliabilitas. Pernyataan dikatakan baik jika konsistensi internal $\left(r_{x y} \geq 0,3\right)$ dan reliabilitas $\left(r_{11} \geq 0,7\right)$. Dari 50 pernyataan yang diujicobakan terdapat 33 pernyataan yang digunakan.

Uji hipotesis dilakukan dengan anava dua jalan dengan sel tak sama. Uji prasyarat analisis untuk uji hipotesis meliputi uji normalitas dengan metode Lilliefors dan uji homogenitas dengan metode Bartlett. Prasyarat normalitas dan homogenitas data telah terpenuhi, maka dilakukan analisis data dengan menggunakan analisis variansi dua jalan dengan sel tak sama selanjutnya dilanjutkan uji komparasi ganda dengan metode Scheffe'

\section{HASIL PENELITIAN DAN PEMBAHASAN}

Setelah hasil uji keseimbangan menyatakan bahwa populasi yang diwakili kelompok eksperimen satu, kelompok eksperimen dua, dan kelompok eksperimen tiga mempunyai kemampuan awal matematika yang sama dan data KBMTT berdistribusi normal dan mempunyai variansi yang homogen, selanjutnya dilakukan uji analisis variansi dua jalan dengan sel tak sama. Rangkuman uji analisis variansi dua jalan dengan sel tak sama disajikan pada Tabel 1.

Tabel 1. Rangkuman Analisis Variansi Dua Jalan

\begin{tabular}{lcccccc}
\hline \multicolumn{1}{c}{ Sumber } & $J K$ & $d k$ & $R K$ & $F_{\text {obs }}$ & $F_{\alpha}$ & Keputusan \\
\hline Model (A) & 15352,482 & 2 & 7676,241 & 54,858 & 3,000 & $H_{0 A}$ ditolak \\
KE (B) & 7518,822 & 2 & 3759,411 & 26,866 & 3,000 & $H_{0 B}$ ditolak \\
Interaksi (AB) & 650,043 & 4 & 162,510 & 1,161 & 2,370 & $H_{0 A B}$ diterima \\
Galat (G) & 34282,164 & 245 & 139,927 & - & - & - \\
Total & 57803,511 & 253 & - & - & - & - \\
\hline
\end{tabular}

Berdasarkan Tabel 1 diperoleh kesimpulan sebagai berikut. (1) terdapat perbedaaan signifikan KBMTT peserta didik berdasarkan model pembelajaran; (2) terdapat perbedaaan signifikan KBMTT peserta didik ditinjau dari kecerdasan emosional peserta didik; (3) tidak terdapat interaksi yang signifikan antara model pembelajaran dengan kecerdasan emosional peserta didik terhadap KBMTT.

Berdasarkan hasil analisis variansi dua jalan dengan sel tak sama diperoleh bahwa $H_{0 A}$ ditolak dan $H_{O B}$ ditolak. Dengan demikian, perlu dilakukan uji lanjut antar baris, uji lanjut antar kolom dan uji lanjut antar sel pada baris yang sama. Dalam penelitian ini uji lanjut menggunakan uji komparasi ganda metode Scheffe'. Sebelum melihat hasil uji komparasi ganda, berikut disajikan rangkuman rataan antar sel lengkap dengan rataan marginalnya pada Tabel 2 . 
Tabel 2. Rerata Masing-Masing Sel dan Rerata Marginal

\begin{tabular}{ccccc}
\hline \multirow{2}{*}{$\begin{array}{c}\text { Model } \\
\text { Pembelajaran }\end{array}$} & \multicolumn{3}{c}{ Kecerdasan Emosional } & Rerata Marginal \\
\cline { 2 - 5 } & Tinggi & Sedang & Rendah & \\
\hline PBL & 54,711 & 45,17 & 36,823 & 44,554 \\
DL & 38,408 & 30,939 & 23,262 & 31,052 \\
TPS & 31,393 & 26,016 & 23,05 & 26,892 \\
Rerata Marginal & 40,195 & 34,517 & 28,291 & \\
\hline
\end{tabular}

Dari hasil perhitungan anava diperoleh $H_{0 A}$ ditolak, berarti terdapat perbedaaan signifikan KBMTT peserta didik berdasarkan model pembelajaran. Adanya tiga baris maka perlu dilanjutkan dengan uji Scheffe' untuk komparasi antar baris. Hasil uji Scheffe' untuk komparasi antar baris dapat dirangkum dalam Tabel 3.

Tabel 3. Rangkuman Uji Scheffe Komparasi Antar Baris

\begin{tabular}{cccc}
\hline$H_{0}$ & $F_{\text {obs }}$ & Nilai Kritis $\left(2 F_{0,05 ; 2,245}\right)$ & Keputusan Uji \\
\hline$\mu_{1 .}=\mu_{2 .}$ & 55,743 & 6,000 & $H_{0}$ ditolak \\
\hline$\mu_{1 .}=\mu_{3 .}$ & 94,813 & 6,000 & $H_{0}$ ditolak \\
\hline$\mu_{2 .}=\mu_{3 .}$ & 5,167 & 6,000 & $H_{0}$ diterima
\end{tabular}

Berdasarkan Tabel 3 diperoleh kesimpulan sebagai berikut: (1) peserta didik dengan perlakuan model pembelajaran PBL mempunyai KBMTT yang lebih baik dibanding dengan peserta didik dengan perlakuan model pembelajaran DL. (2) peserta didik dengan perlakuan model pembelajaran PBL mempunyai KBMTT yang lebih baik dibanding dengan peserta didik dengan perlakuan model pembelajaran TPS. (3) peserta didik yang diberi perlakuan model pembejaran DL dan TPS memberikan KBMTT yang sama baiknya. (1) dan (2) hasilnya sesuai dengan hipotesis bahwa KBMTT peserta didik yang dikenai dengan model PBL lebih baik dari pada dengan model DL dan TPS. Hal ini karena masalah yang baik yang disiapkan oleh guru akan memotivasi peserta didik untuk menyelidiki pengertian yang lebih dalam tentang suatu konsep. Ini dapat dilakukan dengan mengkaitkan subjek dengan dunia nyata sehingga dalam memecahkan masalah peserta didik terlibat. Hal ini senada dengan penelitian yang dilakukan oleh Herman (2007), bahwa pembelajaran berbasis masalah terbuka dan struktur lebih baik dalam meningkatkan kemampuan matematis tingkat tinggi peserta didik ditinjau berdasarkan kualifikasi sekolah dan kecerdasan peserta didik.

Hasil yang berbeda diperoleh dari uji komparasi ganda antar model DL dan TPS. Hipotesis nol tidak ditolak, hal ini berarti model DL dan TPS memberikan efek yang sama terhadap KBMTT. Ini tidak sesuai dengan hipotesis yang menyatakan bahwa KBMTT peserta didik dengan menggunakan model DL lebih baik dari pada TPS. Kemungkinan hasil penelitian yang sama tersebut terjadi karena peneliti kurang 
memperhatikan adanya beberapa peserta didik anggota kelompok yang kurang aktif berdiskusi dengan kelompoknya untuk menemukan konsep kubus dan balok ketika proses pembelajaran berlangsung, mereka hanya menyalin hasil diskusi dari temannya sehingga KBMTT kurang baik

Dari hasil perhitungan anava diperoleh $H_{O B}$ ditolak, berarti berarti terdapat perbedaaan signifikan KBMTT peserta didik ditinjau dari kecerdasan emosional peserta didik.. Adanya tiga kolom maka perlu dilanjutkan uji Scheffe' untuk komparasi antar kolom. Hasil uji Scheffe' untuk komparasi antar kolom dapat dilihat pada Tabel 4.

Tabel 4. Rangkuman Uji Scheffe Komparasi Antar Kolom

\begin{tabular}{cccc}
\hline$H_{0}$ & $F_{\text {obs }}$ & Nilai Kritis $\left(2 F_{0,05 ; 2,245}\right)$ & Keputusan Uji \\
\hline$\mu_{\cdot 1}=\mu_{\cdot 2}$ & 9,949 & 6,000 & $H_{0}$ ditolak \\
\hline$\mu_{\cdot_{1}}=\mu_{\cdot_{3}}$ & 35,964 & 6,000 & $H_{0}$ ditolak \\
\hline$\mu_{\cdot_{1}}=\mu_{\cdot_{3}}$ & 12,151 & 6,000 & $H_{0}$ ditolak \\
\hline
\end{tabular}

Berdasarkan Tabel 4 diperoleh kesimpulan sebagai berikut. (1) peserta didik dengan kategori kecerdasan emosional tinggi mempunyai KBMTT yang lebih baik dibanding kategori kecerdasan emosional sedang. (2) peserta didik dengan kategori kecerdasan emosional tinggi mempunyai KBMTT yang lebih baik dibanding kategori kecerdasan emosional rendah. (3) peserta didik dengan kategori kecerdasan emosional sedang mempunyai KBMTT yang lebih baik dibanding kategori kecerdasan emosional rendah. Ketiga kesimpulan tersebut sesuai hipotesis dalam penelitian ini. Hal ini senada dengan penelitian Chabeli (2006) menyatakan ada hubungan antara pemikiran kritis dan kecerdasan emosional dalam berpikir kritis menyediakan alat-alat mental diperlukan secara eksplisit memahami bagaimana penalaran bekerja dan bagaimana alat tersebut dapat digunakan untuk mengambil perintah dari apa yang kita berpikir, merasa, keinginan dan melakukan.

Dari hasil perhitungan anava diperoleh $H_{O A B}$ tidak ditolak, berarti tidak ada interaksi antara model pembelajaran dan kecerdasan emosional peserta didik terhadap KBMTT pada materi kubus dan balok. Hal tersebut menunjukkan bahwa pengaruh model pembelajaran terhadap KBMTT tidak tergantung pada tingkatan kecerdasan emosional peserta didik.

Berdasarkan uraian tersebut, dapat disimpulkan sebagai berikut.

a. Pada model pembelajaran PBL, DL dan TPS, KBMTT peserta didik yang memiliki kecerdasan emosional tinggi lebih baik dibandingkan peserta didik yang memiliki kecerdasan emosional sedang dan rendah, serta KBMTT peserta didik yang memiliki kecerdasan emosional sedang lebih baik dibandingkan peserta didik yang memiliki kecerdasan emosional rendah. 
b. Pada kategori kecerdasan emosional tinggi, sedang maupun rendah, KBMTT peserta didik yang diberi model pembelajaran PBL lebih baik daripada model pembelajaran DL dan model pembelajaran TPS. Selain itu KBMTT peserta didik yang diberi model pembelajaran DL sama baik dengan model pembelajaran TPS.

Hal ini kemungkinan karena penggunaan model pembelajaran mempunyai hubungan yang sangat besar terhadap kecerdasan emosional peserta didik. Penggunaan PBL pada proses pembelajaran mampu menghadirkan kecerdasan emosional peserta didik pada setiap fase pembelajarannya. Akibatnya, pada peserta didik dengan kecerdasan emosional tinggi, sedang dan rendah, penggunaan PBL menghasilkan KBMTT lebih baik daripada model pembelajaran DL dan model pembelajaran TPS. Hal ini senada dengan penelitian Ibrahim (2012) bahwa kehadiran kecerdasan emosional pada pembelajaran matematika berbasis-masalah akan mendukung atau memandu kegiatankegiatan yang dilakukan peserta didik mulai dari fase pertama pembelajaran hingga fase akhir pembelajaran, sehingga diperolehnya hasil pembelajaran matematik secara utuh.

\section{SIMPULAN DAN SARAN}

Berdasarkan analisis data dari penelitian yang dilakukan, dapat disimpulkan sebagai berikut. (1) Model pembelajaran PBL memberikan KBMTT yang lebih baik dibanding model pembelajaran DL. Model pembelajaran PBL memberikan KBMTT yang lebih baik dibanding model pembelajaran TPS. Model pembelajaran DL dan TPS memberikan KBMTT yang sama baiknya. (2) Peserta didik dengan kecerdasan emosional tinggi memiliki KBMTT yang lebih baik dari pada peserta didik yang memiliki kecerdasan emosional sedang dan rendah, sedangkan peserta didik dengan kecerdasan emosional sedang memiliki KBMTT yang lebih baik dari pada peserta didik dengan kecerdasan emosional rendah. (3) Pada model pembelajaran PBL, DL dan TPS, KBMTT peserta didik yang memiliki kecerdasan emosional tinggi lebih baik dibandingkan peserta didik yang memiliki kecerdasan emosional sedang dan rendah, serta KBMTT peserta didik yang memiliki kecerdasan emosional sedang lebih baik dibandingkan peserta didik yang memiliki kecerdasan emosional rendah.(4) Pada kategori kecerdasan emosional tinggi, sedang maupun rendah, KBMTT peserta didik yang diberi model pembelajaran PBL lebih baik daripada model pembelajaran DL dan model pembelajaran TPS. Selain itu KBMTT peserta didik yang diberi model pembelajaran DL sama baik dengan model pembelajaran TPS.

Berdasarkan simpulan hasil penelitian, peneliti atau calon peneliti lain dapat meneruskan atau mengembangkan penelitian ini karena hasil penelitian ini hanya terbatas 
pada materi kubus dan balok, sehingga peneliti lain bisa menerapkan model pembelajaran dalam penelitian ini pada materi matematika yang lain karena model pembelajaran PBL, DL dan TPS cocok diterapkan pada semua mata pelajaran pada jenjang pendidikan SMP maupun SMA.

\section{DAFTAR PUSTAKA}

Asep. 2010. Pengaruh Pembelajaran Berbasis Masalah Dengan Setting Kooperatif Tipe Jigsaw Terhadap Pencapaian Kemampuan Berpikir Matematik Tingkat Tinggi Dan Kemandirian Belajar Siswa SMA. Disertasi. UPI Bandung : Tidak Dipublikasikan.

Chabeli, M. 2006. Higher order thingking skills competencies required by outcomesbased education from learner. Artikel Penelitian. University of Johannesburg: Tidak Dipublikasikan.

Depdiknas. 2014. Panduan Umum Olimpiade Sains Nasional 2014. Jakarta: Direktorat Jendral Pendidikan Menengah

Goroshit, M. Dan Hen, M. 2012. Emotional Intelligence: A Stable Change?. International Journal of Teaching and Learning in Higer Education, vol. 24, No 1, hlm. 31- 42.

Herman, T. 2007. Pembelajaran Berbasis Masalah untuk Meningkatkan Kemampuan Berpikir Matematis Tingkat Tinggi Siswa Sekolah Menengah Pertama (SMP), Disertasi UPI. Bandung

Hosnan, M. 2014. Pendekatan Saintifik dan Konstektual Dalam Pembelajaran Abad 21. Bogor: Graha Indonesia.

Ibrahim. 2012. Pembelajaran Matematika Berbasis Masalah yang Menghadirkan Kecerdasan Emosional. Jurnal Ilmiah Program Studi Matematika STKIP Siliwangi Bandung, vol. 1, no. 1,hlm. 46.

Soebyakto, BB. 2012. An Empirical Testing of Intelligence, Emotional and Spiritual Qoutients Quality of Manager using Structural Equation Modeling. International Journal of Independent Reasearch And Studies, vol. 1, No.1, hlm. 1-12.

Suardana, K. 2012. Pendampingan Penyusunan Asesmen Fisika Berbasis OSN Bagi Guru SMP Negeri Di Kota Tabanan. Laporan Pengabdian Masyarakat. Universitas Pendidikan Ganesha. Tidak Dipublikasikan.

Suparlan, A. 2005. Pembelajaran Berbasis Masalah Untuk Mengembangkan Kemampuan Pemahaman Dan Representasi Matematik Siswa Sekolah Menengah Pertama. Tesis. UPI Bandung : Tidak Dipublikasikan.

Suryadi, D. 2005. Penggunaan Pendekatan Pembelajaran Tidak Langsung Serta Pendekatan Gabungan Langsung Dan Tidak Langsung Dalam Rangka Meningkatkan Kemampuan Berpikir Tingkat Tinggi Siswa SLTP. Disertasi. UPI Bandung : Tidak Dipublikasikan. 
Suwaji. 2008. Permasalahan Pembelajaran Geometri Ruang SMP dan Alternatif Pemecahannya. Yogyakarta : PPPPTK Matematika

Thomson, T. 2008. Mathematics Teacher's Interpretation of Higher-Order Thingking In Bloom's Taxonomy. International Electronic Journal of Mathematics Education, vol.3, No.2, hlm. 96 -109.

Tim USAID. 2014. Pembelajaran Matematika SMP di LPTK.Tidak Dipublikasikan. 